\title{
Complement C5b-9 Measurement
}

National Cancer Institute

\section{Source}

National Cancer Institute. Complement C5b-9 Measurement. NCI Thesaurus. Code C158235.

The determination of the amount of complement C5b-9 present in a sample. 